University of Nebraska - Lincoln

DigitalCommons@University of Nebraska - Lincoln

20th \& 21st Century French and Francophone Modern Languages and Literatures, Department Studies International Colloquium

4-2020

\title{
“Nous étions ici pour durer": Memorialization and environmental advocacy in Véronique Tadjo's En Compagnie des Hommes
}

Marda Messay

Follow this and additional works at: https://digitalcommons.unl.edu/ffsc2020

Part of the Comparative Literature Commons, French and Francophone Literature Commons, and the Other French and Francophone Language and Literature Commons

This Presentation is brought to you for free and open access by the Modern Languages and Literatures, Department of at DigitalCommons@University of Nebraska - Lincoln. It has been accepted for inclusion in 20th \& 21st Century French and Francophone Studies International Colloquium by an authorized administrator of DigitalCommons@University of Nebraska - Lincoln. 


\section{"Nous étions ici pour durer": Memorialization and environmental advocacy in Véronique Tadjo's En Compagnie des Hommes}

Detected for the first time in 1976 in Northern Zaire (now the Democratic Republic of Congo) and in Southern Sudan (now South Sudan), the Ebola virus has reemerged periodically mainly in Sub-Saharan Africa. The deadliest outbreak of Ebola occurred in Guinea, eventually spread to Liberia and Sierra Leone from 2014-2016. At the end, there were 28, 652 cases and 11, 325 deaths (cdc.gov). The outbreak generated international news coverage and sparked panic, especially once cases were reported in the U.S., in Spain and in the UK. It also incited Veronique Tadjo's latest work, En compagnie des Hommes (2017), as she explains in an interview published in the Australian Journal of French Studies (2018) : "Étant de la Côte d'Ivoire et connaissant la Guinée et le Libéria ( beaucoup moins la Sierra Leone), je me suis dit que derrière ces images, il y avait des tas d'autres choses qui n'étaient pas dites, qu'il y avait des vies, des êtres, des histoires" (252). Beyond the desire to humanize the outbreak, she also insists on the need to remember the outbreak: “... une fois la maladie déclarée officiellement terminée, eh bien on n’en a plus entendu parler! [...] Je me suis dit qu'on ne pouvait quand même pas oublier quelque chose qui avait été aussi terrifiant. Il faut continuer à réfléchir sur ce qui s'est passé et sur ce que l'avenir pourrait nous réserver" (252). Tadjo's objectives are not surprising considering her previous works, especially L'Ombre d'Imana (2000) in which she undertook the arduous task of commemorating and bearing witness to the 1994 Rwandan genocide as part of the Fest'Africa project, 'Rwanda: écrire par devoir de mémoire'. In the same spirit, with En Compagnie des hommes, Tadjo memorializes the victims and the heroes of the Ebola. The novel reflects this with its polyphonic structure that consists of 16 chapters narrated by different agents that were directly impacted by or implicated in the outbreak. Tadjo includes not only human agents but also includes chapters by a Baobab tree, a bat (the host) and the Ebola virus itself. Through all these narrators, Tadjo voices 
the trauma, the mercilessness of the virus, its sociological and economic impact as well as people's resilience and solidarity. However, I intend to explore the text through an eco-critical lens. After the release of the novel, Tadjo expressed the ecological message of her novel and the relationship between ecology and literature in several interviews. For instance, in "Agir par l'imagination" ( 2018), an interview with Lucile Schmid, she remarks: "Pour que la conscience écologique soit renforcée et disséminée, il est essentiel que les arts accompagnent le travail des scientifiques. La literature a la faculté de s'immiscer dans la vie quotidienne des lecteurs. Elle peut aller ou la science s'arrête. [...] il faut également agir par l'imagination, toucher l'homme dans sa représentation du monde et lui offrir des récits de transformation" (182). As such, I propose an analysis of the ecological issues raised within the text and the techniques she uses to guide the reader. I will begin my analysis with her portrait of the Baobab to demonstrate how the text bears witness to the connection between the inhabitants of the region and the environment, as well as the inhabitants' environmentally violent practices. I will then study how, through several narrators, Tadjo depicts the negative impact of the Ebola virus on people's connection to the natural world. Lastly, I will examine how Tadjo's text expresses her hope of renewing human beings' respect for nature. In this paper, I will argue that En compagnie des Hommes is a memorial to the environment and a call to action.

Tadjo gives a voice to the Baobab in the second section of the novel "L'Arbre à Palabres", which follows "le commencement", a very brief section on the beginning of the outbreak from the perspective of an omniscient narrator. In an interview with LePoint, Tadjo identifies a possible origin for the use of a tree as a narrator. She describes a visit to an Ebola Center in Abidjan: "À côté du centre, il y avait un immense arbre qui jetait son ombre sur le centre. J'ai vu cet arbre et je me suis dit, s'il s'etait passé, qu'est-ce qu'il aurait vu, qu'est-ce qu'il aurait entendu?". However, 
the specific choice of a Baobab merits a closer examination considering its importance within the African imagination, as a symbol of wisdom, tradition, life and peace. For instance, in the Ken Bugul's Le Baobab fou (1982), the Baobab, which is firmly rooted in the soil and sustains life in the community, stands for tradition and continuity. It serves as a point of reference for the main character's departure from her village and her subsequent alienation. Even more recently, a metallic 40ft baobab, The Saga of the Baobab, by the Haitian artist Edouard Duval-Carrié, was installed in the central atrium of the new Musée des Civilisations Noires in Dakar, Senegal, inaugurated in December 2018. The Baobab, national symbol in Senegal, greets visitors as they step into the museum and explore a space described as "un lieu d'études, de prospection et de production de savoirs sur le monde noir dans une contemporanéité globale" (http://www.mcn.sn/). Tadjo's Baobab adheres to this tradition by assuming the role of a traditional storyteller, who will educate his audience about the past and transmit the core values and beliefs of the community. This immersion into the past begins with the anthropomorphization of the Baobab, which plunges the reader into the fantastical world of traditional African Storytelling: "Nous, les arbres. Nos racines plongent jusqu'au coeur de la terre dont nous sentons battre le pouls. Nous respirons son haleine. Goûtons sa chair. Nous naissons et mourons au même endroit sans jamais nous éloigner de notre territoire" (21). As Emmanuel Obiechina explains in "Transition from oral to literary tradition" (1967), storytellers in traditional African communities presented "an undifferentiated world within which the dichotomy between the natural and the supernatural, the abstract and the concrete, the physical and the metaphysical does not exit. Here animals, plants, objects, natural forces and abstract entities like song, laughter and dance are humanized" (155). The Baobab presents himself as a part of the community and an integral part of every aspect of life: "J'étais l'arbre de la sagesse, celui vers qui l'on se tournait lorsqu'il fallait trouver une réponse aux 
tourments de l'existence [...] Je riais avec eux. Je pleurais avec eux, quand la tristesse envahissait le village" (28-29). It is evident that the Baobab has the authority and the knowledge to speak about the past and the community. He illustrates the symbiosis of the inhabitants and their environment and the mutual respect that existed between them: “C'est ainsi que j'ai vécu avec les hommes de mon village. Je les écoutais, ils entendaient le murmure de mes feuilles. Chacun à sa place, mais tous ensemble" (32). He also explains the interconnectedness of all creatures on earth by explaining the importance of forests and trees for animals but also the fundamental production of oxygen (23). While the Baobab shares this idyllic portrait of the past, he also bears witness to the environmental destruction caused by the inhabitants by attesting to their exploitative attitudes and its devastating effects on the environment: "Les hommes brûlent nos branches, saignant nos troncs. Pour atteindre et exploiter une zone où s'élèvent des arbres d'une grande sagesse, ils coupent sans pitié. Ils ne voient en nous qu'une valeur d'échange. Regardez comme nos sols s'effritent et perdent de leur substance! L'humus riche et parfumé s'assèche. La roche au visage dur fait surface. J'ai vu des animaux mourir de faim, nous privant de leur amitié" (23-24). The Baobab places the blame for this degradation on the capitalist-driven global timber industry and the discovery and subsequent mining of gold in the region, which led to massive deforestation, the resulting closer contact of wildlife and humans, the seeping of mercury (used to find particle of gold) into the water, and the rise of diseases $(27,32)$. He also identifies war, drought and famine as factors in the environmental devastation of the region as they cause the poor and refugees to seek refuge in the forests and to negatively impact the environment with their hunting and farming (27). The environmental impact of these actions may be easier to visualize as they have been widely studied and documented, however, the Baobab also explains the cultural destruction that ensued: "Les villageois se transformèrent en une armée de fourmis Magnan, prédatrices 
redoutables, déterminées à tout anéantir sur leur passage. Il fallait faire table rase du passé. Du jour au lendemain, ils délaissèrent leurs champs, leurs légendes, leurs coutumes, leurs croyances $[\ldots]$ Ils m'avaient irrémédiablement tourné le dos, malgré des générations de respect mutuel" (33). The Baobab ends his narration by bearing witness to the beginning of the Ebola epidemic (linked to the degradation of the environment), the devastation it caused and the bravery of people: "Rien de ce qui fait les êtres humains ne m'a échappé. Je veux raconteur leurs histoires, donner une voix à tous ceux qui se sont élevés au-dessus de la frayeur" (37). While the majority of the Baobab's narration calls into question and condemns the inhabitants' voracity and the irreparable damages it causes, the Baobab also identifies the possibility of repairing their connection with the environment, with each other, and with the past : “ La terre est une histoire que nous n'avons pas fini de conter, une histoire de naufragés perdus sur une île" (37). The rest of Tadjo's novel illustrates the impact of the virus on the local people's relationship with the environment and this potential redemption.

The next section of the novel, "Lutter de toutes ses forces Encore Lutter" consists of 10 chapters narrated by humans engaged in the fight against the virus or victims of the virus. They include a doctor, a nurse, a gravedigger, an infected mother, a survivor, a chief administrative officer, an infected foreign volunteer, an extended family member in charge of a child orphaned by the virus, a poet whose fiancé is infected, and a Congolese researcher. Each person shares their perspective on the political, economic and social impact of the virus. For example, the nurse (chapter V) explains how the epidemic impacts women more than men due to their status and place in the household and community. She also describes the extent to which health systems are poorly funded and ill-equipped, as well the corruption and the inequalities that make combatting the virus more difficult (55-65). Therefore, it is not surprising that Tadjo would also use these narrators to 
reveal its impact on the community's relationship with the environment and echo some of the themes she explored in the Baobab's narration. For instance, the survivor, chapter VIII, talks about a tree next to the Center where she received treatment and ultimately was cured: "J'ai pu quitter mon lit et je me suis remise à marcher. À petits pas prudents. Je suis allée vers l'arbre, vers son réconfort offert à nous dans la profondeur de notre malheur. Quand je m'appuyais contre lui, je le sentais vibrer en ondes profondes. Je posais mon oreille sur son tronc rugueux et il me parlait, chuchotant qu'il était avec moi. J'ai passé maintes fois mes bras autour de sa taille” (90-91). While it is obviously related to Tadjo's visit to the Center in Abidjan, it reminds the reader of the Baobab's chapter, and suggests that the inhabitants' past reverence and respect for nature can be reinvigorated despite past failings. The two most relevant chapters are those of the gravedigger and the Congolese researcher as they explicitly identify the environmental aspects to consider in understanding the virus's impact.

The gravedigger's narration, chapter VI, focuses on the changes that ensued in the community's relationship with the natural world, in the context of death and burials. Nature is considered the dwelling place of ancestors. This is exemplified in Birago Diop's poem "Souffles" (1951): “les morts ne sont pas sous la terre:/ ils sont dans l'arbre qui frémit,/ ils sont dans le bois qui gémit, ils sont dans l'eau qui coule ....”. As such, specific funeral rituals are used to facilitate the transition between this world and the next. As Lesiba Bayoli and Molebogeng MakobeRabothata explains in "The African conception of death: A cultural implications" (2014): "The performance of these rituals is seen as important in maintaining balance and harmony between the living and the living dead. This is the basis on which the connection between the physical and spiritual ontologies is maintained and enhanced" (237). The gravedigger's narration illustrates how this connection is damaged by the inability to practice traditional funeral rites and by the spraying 
of Chlorine: "Quand nous descendons un cadavre dans la tombe fraîchement creusée, le pulvérisateur s'approche et pompe du chlore dans le trou et sur le sol tout autour. Pas de prières. Pas de pleurs. Juste une croix en bois blanc" (69). It is beneficial to contrast this scene with a traditional funeral scene within the text, included in the Baobab's portrait of the past, where the Baobab would be used as a tomb and the villagers would celebrate, sing, dance around the dead. The villagers would touch the dead and even speak to the dead (29). The victims of the Ebola virus and their families were not able to participate in this harmonious transition, which is evident in the gravedigger's description of the presence of ghosts: “... ce sont des esprits perdus qui ne veulent pas quitter la terre, ils aimeraient qu'on les aide à revenir. Leurs tentatives pour nous intimider ne sont que des appels de détresse"(71). The gravedigger's narration exposes how the Ebola virus, a consequence of the inhabitants' dangerous environmental practices, further damaged their connection with the natural world and the spiritual world. This perspective is further expanded in the Congolese researcher's chapter (chapter XIII), in which he describes the fight against Ebola from a scientific perspective. More importantly, he discusses the role of the traditional healer, the guérisseur, in this fight. He admits their inability to offer viable 'natural' cures for the virus, but he does highlight their primordial role in the community, specifically their teachings on humans' symbiosis with nature: "Dans les villages et dans certains quartiers de la ville, le guérisseur détient une connaissance ancestrale. Sa parole rassurante et ses gestes rituels se nourissent d'un passé refusant de céder la place. Rival de taille. Ceux qui jettent un regard méprisant sur son autorité sont condamnés à l'erreur. Pour les savants de la médecine traditionnelle, ce n'est pas seulement de plantes et de végétaux qu'il s'agit. C'est toute une conception du monde qui s'exprime, une manière de vivre avec la faune et la flore" (135). While the inhabitants' devastation of the environment ultimately led to an inability to use the natural world to heal, the belief systems that 
extolled the connection between the natural world and the human world must be integrated into their environmental practices in order to move forward into the future.

Tadjo further articulates her ecological message in the last two sections of the novel, "Au fin de la forêt", narrated by the Ebola virus and a bat (the host), and "l'épidemie est enrayée", narrated by the Baobab. Just like the Baobab, the use of anthropomorphized animals has a long tradition in African literature. For instance, there are folk-tales with animals that think, talk, behave like humans. As Kofi Opoku notes in "Animals in African mythology": "Much of African proverbial wisdom is acquired from meditating upon animals who are used as a means by which humans meditate upon themselves, and the animals who are portrayed in art perform the same function for humans"(353). While the anthropomorphization of the Baobab at the beginning of the text immersed the reader into the ancestral context, the anthropomorphization of the virus and the bat can be considered as "strategic anthropomorphism", which "occurs when the lines between humans and non-humans are blurred to undercut notions of superiority and to bring about ecological awareness and/ or restoration" (Iheka 14). The Ebola virus' and the Bat's narrations criticize the inhabitants' dangerous environmental practices. For instance, the Ebola virus denounces their violence against nature, which made it impossible to remain in the untouched part of the forest: "Ce n'est pas moi qui ai changé. Ce sont les hommes qui ont changé de direction. La vie qu'ils mènent n'est plus celle des ancêtres. Ils sont devenus plus exigeants, avides et prédateurs. Leurs envies n'ont pas de limite"(143). The bat expresses similar thoughts: "Il dormait en moi avant que les hommes ne viennent gâcher la splendeur de la forêt”(153). However, they also establish the fundamental notion that humans and non-humans are cohabitants of the same space and how humans need to recognize their responsibility in this interconnectedness and adjust their behavior accordingly. As the bat declares in the last part of his narration: "Prendre, une fois pour 
tous, conscience du péril qu'ils font peser sur leur propre espèce et sur toute la biosphère et utiliser leur remarquable intelligence pour éviter la fin du monde. Coloniser l'espace avec leurs grandes fusées ne sera pas une planche de salut pour les hommes. Car s'ils n'ont pas appris à vivre ici, comment pourront-ils vivre dans l'Aillleurs lointain" (159). It is important to note this reference to the space race as it establishes the idea that the devastation of the environment and the protection of the environment is not a local issue, but a global issue. The Baobab ends En compagnie des hommes by echoing the bat's hope for the future as he describes the elation once the virus was eradicated: "Du désastre peut surgir la ténacité d'un renouveau. Tout se passe par en bas, tout se passe sous la terre. Je donnerai aux arbisseaux le suc de mes racines. Et le destin des hommes rejoindra le nôtre"(167). By the end, it is evident how Tadjo's novel not only calls into question the practices that endanger the environment, which in turn endanger humans on multiple levels, but also expresses her hope of renewing human beings' respect for nature.

In conclusion, while En compagnie des hommes clearly memorializes the victims and the heroes of the Ebola virus, it also memorializes the environment by bearing witness to the interconnectedness of the inhabitants of the region and the environment, the environmental devastation caused by the inhabitants and the resulting rupture with the natural and spiritual world. It also acts as a call to action for humans to salvage what is left and to protect the natural world for the future. As the Baobab eloquently states: "Nous avons connu les plus belles et les plus tristes histoires, et nous serons témoins d'autres cycles de vie. C'est ainsi que se joue le passage des jours. Nous étions ici pour durer" (22). 